\title{
Mapping the hidden diversity of the Geophagus sensu stricto species group (Cichlidae: Geophagini) from the Amazon basin
}

\author{
Aline Mourão Ximenes ${ }^{\text {Corresp., } 1,2}$, Pedro Senna Bittencourt ${ }^{1}$, Valéria Nogueira Machado ${ }^{1}$, Tomas Hrbek ${ }^{1,3}$, Izeni \\ Pires Farias ${ }^{\text {Corresp. } 1}$ \\ 1 Departamento de Genética, Instituto de Ciências Biológicas, Universidade Federal do Amazonas, Manaus, Amazonas, Brazil \\ 2 Programa de Pós-Graduação em Genética, Conservação e Biologia Evolutiva, Instituto Nacional de Pesquisas da Amazônia, Manaus, Amazonas, Brazil \\ 3 Biology Department, Trinity University, San Antonio, Texas, US
}

Corresponding Authors: Aline Mourão Ximenes, Izeni Pires Farias

Email address: alineximenesbio@gmail.com, izeni@evoamazon.net

South American freshwater ichthyofauna is taxonomically the most diverse on the planet, yet its diversity is still vastly underestimated. The Amazon basin alone holds more than half of this diversity. The evidence of this underestimation comes from the backlog of morphologically distinct, yet undescribed forms deposited in museum collections, and from DNA-based inventories which consistently identify large numbers of divergent lineages within even well-studied species groups. In the present study, we investigated lineage diversity within the Geophagus sensu stricto species group. To achieve these objectives, we analyzed 337 individuals sampled from 77 locations within and outside the Amazon basin representing 10 nominal and 6 morphologically distinct but undescribed species. We sequenced the mitochondrial cytochrome c oxidase subunit I (COI) and delimited lineages using four different single-locus species discovery methods (mPTP - 15 lineages; LocMin 14 lineages; bGMYC - 18 lineages; and GMYC - 30 lineages). The six morphologically distinct but undescribed species were also delimited by the majority of the species discovery methods. Five of these lineages are restricted to a single collection site or a watershed and their habitats are threatened by human activities such as deforestation, agricultural activities and construction of hydroelectric plants. Our results also highlight the importance of combining DNA and morphological data in biodiversity assessment studies especially in taxonomically diverse tropical biotas. 
1 Mapping the hidden diversity of the Geophagus sensu stricto species group (Cichlidae:

2 Geophagini) from the Amazon basin

3

4 Aline Mourão Ximenes ${ }^{1,2}$, Pedro Senna Bittencourt ${ }^{1}$, Valéria Nogueira Machado ${ }^{1}$, Tomas

5 Hrbek $^{1,3}$, Izeni Pires Farias ${ }^{1}$

6

7

8 ' ${ }^{1}$ Laboratório de Evolução e Genética Animal (LEGAL), Departamento de Genética,

9 Universidade Federal do Amazonas, Manaus, Amazonas, Brazil.

$10{ }^{2}$ Programa de Pós-Graduação em Genética, Conservação e Biologia Evolutiva, Instituto

11 Nacional de Pesquisas da Amazônia, Manaus, Amazonas, Brazil.

$12{ }^{3}$ Biology Department, Trinity University, San Antonio, Texas, US.

14 Corresponding Authors:

15 Aline Ximenes

16 Av. General Rodrigo Octávio Jordão Ramos 6200 - Coroado I, Manaus, Amazonas, 69080-900,

17 Brazil.

18 E-mail address: alineximenesbio@gmail.com

Izeni Farias

Av. General Rodrigo Octávio Jordão Ramos 6200 - Coroado I, Manaus, Amazonas, 69080-900, Brazil.

E-mail address: izeni@evoamazon.net

\section{Abstract}

South American freshwater ichthyofauna is taxonomically the most diverse on the planet, yet its diversity is still vastly underestimated. The Amazon basin alone holds more than half of this diversity. The evidence of this underestimation comes from the backlog of morphologically distinct, yet undescribed forms deposited in museum collections, and from DNA-based inventories which consistently identify large numbers of divergent lineages within even wellstudied species groups. In the present study, we investigated lineage diversity within the Geophagus sensu stricto species group. To achieve these objectives, we analyzed 337 individuals sampled from 77 locations within and outside the Amazon basin representing 10 nominal and 6 morphologically distinct but undescribed species. We sequenced the mitochondrial cytochrome $\mathrm{c}$ oxidase subunit I (COI) and delimited lineages using four different single-locus species 
37 discovery methods (mPTP - 15 lineages; LocMin - 14 lineages; bGMYC - 18 lineages; and 38 GMYC - 30 lineages). The six morphologically distinct but undescribed species were also

39

40

41

42

43

44

45

46

47

48

49

50

51

52

53

54

55

56

57

58

59

60

61

62

63

64

65

66

67

68

delimited by the majority of the species discovery methods. Five of these lineages are restricted to a single collection site or a watershed and their habitats are threatened by human activities such as deforestation, agricultural activities and construction of hydroelectric plants. Our results also highlight the importance of combining DNA and morphological data in biodiversity assessment studies especially in taxonomically diverse tropical biotas.

\section{Introduction}

South American freshwater ichthyofauna is the most diverse on the planet with more than 5,150 valid described species ( Reis et al., 2016). The Amazon River basin alone holds more than half of this diversity (52\% - 2,716 valid species) (Dagosta \& De Pinna, 2019), even though extensive areas to the north and south of the main river channel still remain poorly sampled (Reis et al., 2016). The evolution of this astonishing diversity resulted from continent-wide geomorphological processes forming and reshaping the Amazon basin hydrological network beginning in the Miocene, and climatic oscillations beginning in the Pliocene (Montoya-Burgos, 2003; Hubert \& Renno, 2006; Lovejoy, Albert \& Crampton, 2006; Reis et al., 2016; Bloom \& Lovejoy, 2017). These processes have resulted in not only vicariance and geodispersal of entire fish communities (Dagosta \& De Pinna, 2018), but also have generated an environmentally, physico-chemically and structurally heterogeneous landscape (Rodríquez et al., 2007; GregoryBogotá et al., 2020). Therefore, environmental heterogeneity, climate, ecological and historical factors have an important role in explaining the current diversity of Amazonian fishes (Oberdorff et al., 2019).

Sequences of the mitochondrial DNA gene cytochrome c oxidase (COI) are often used to assist taxonomy and species identification following the DNA barcoding principles (Hebert, Ratnasingham \& DeWaard, 2003; Hajibabaei et al., 2007). They can also be used for biodiversity inventories (Monaghan et al., 2009; Carvalho et al., 2011; Pereira et al., 2013; Machado et al., 2018), allowing rapid characterization of not just a given sample but of entire communities (Carvalho et al., 2018; Machado et al., 2018; Souza et al., 2018; Arruda et al., 2019; Santos et al., 2019). The simplest approach to delimit species from DNA sequence data is to use the percent cut-off rule (Fujisawa \& Barraclough, 2013), such as the $2 \%$ intra vs. interspecific divergence

Peer) reviewing PDF | (2021:06:63116:1:0:NEW 7 Oct 2021) 
69

70

71

72

73

74

75

76

77

78

79

80

81

82

83

84

85

86

87

88

89

90

91

92

93

94

95

96

97

98

cut-off for freshwater fishes (Pereira et al., 2011, 2013). There are also methods that automatically optimize the cut-off percentage for a given sample (e.g. ABGD, Locmin) (Brown et al., 2012; Puillandre et al., 2012). However, distance-based methods are weakly connected to evolutionary theory (Fujisawa \& Barraclough, 2013), since they ignore evolutionary relationships of the taxa involved and rely on sequence similarity thresholds that are not necessarily biologically relevant (Kapli et al., 2017).

On the other hand, the pattern of evolutionary relationships of taxa accurately reflects the processes that resulted in the gene trees, consequently, permitting differentiation between intra and interspecific patterns of evolutionary relationship (Fujisawa \& Barraclough, 2013). Several coalescent and movement-based algorithms capable of accurately differentiating between intra and inter specific patterns of phylogenetic relationships have been implemented (e.g.,Reid \& Carstens, 2012; Fujisawa \& Barraclough, 2013; Zhang et al., 2013; Kapli et al., 2017). Despite the limitations of inference from single locus data (Fujisawa \& Barraclough, 2013; Dellicour \& Flot, 2018), single locus species delimitation methods (SLSD) provide a robust framework for species discovery. They identify unique evolutionary histories even if conflicting with genomic data, and they often provide an initial hypothesis for the existence of new species within a given dataset stimulating taxonomic studies (Ota et al., 2020).

Recent DNA-barcoding inventories and the usage of SLSD methods indicate that for some fish families widely distributed across the Amazon basin (e.g., Cichlidae and Serrasalmidae), the underestimation of diversity appears to be broadly concordant with Reis et al. (2016), who estimated that $34 \%-42 \%$ of Neotropical freshwater fishes remain undescribed. This is also consistent with the study of Melo et al. (2021), who studied patterns of diversification of Characoid fishes, and identified a burst of diversification in Anostomidae, Serrasalmidae and Characidae families. DNA-based species discovery analyses focusing on lower taxonomic units such as genera of cichlids, also discovered multiple divergent evolutionary lineages [e.g., Astronotus Swainson, 1839 (Colatreli et al., 2012); Apistogramma Regan, 1913 (Tougard et al., 2017); Gymnogeophagus Miranda-Ribeiro, 1918 (Říčan et al., 2018); Australoheros Ř́čan \& Kullander, 2006 (Ottoni et al., 2019); and Geophagus Heckel,1840 (Alves-Silva \& Dergam, 2014; Carvalho et al., 2018; Argolo et al., 2020)] suggesting cryptic diversity and, possibly, undescribed species. 
The cichlid genus Geophagus comprises 31 species of eartheaters (Fricke, Eschmeyer \& 100 Van der Lann, 2020) grouped into three species groups (Kullander, 1998; López-Fernández \& 101 Taphorn, 2004). These species groups came into use after Kullander's (1986) revision of the 102 genus, which restricted Geophagus to include only species with paired caudal extensions of the 103 swim bladder supported by epihemal ribs, and greater number of caudal than abdominal 104 vertebrae - morphological features absent in the species of the 'G.' steindachneri and 'G.'

105 106 107 108 109 110 brasiliensis species groups. The three groups also have allopatric distribution in the Neotropics: The Geophagus sensu stricto species group, with 20 species is distributed within the Amazon, Orinoco, Parnaiba, and northern Atlantic coast river basins; the 'Geophagus' steindachneri species group, with three trans-Andean species is distributed in Panamá, Colombia and Venezuela; and the 'Geophagus' brasiliensis species group, with eight species is distributed in eastern South American river basins. While the 'Geophagus' steindachneri and 'Geophagus' brasiliensis species groups have been left without a formal generic assignment (Argollo et al., 2020) and their phylogenetic relationships remains unclear (López-Fernández, Winemiller \& Honeycutt, 2010; Ilves, Torti \& López-Fernández, 2018), this has not impeded active taxonomic interest in these species groups. Recently an integrative taxonomic analysis of the ' $G$.' brasiliensis species group using SLSD methods, multilocus RADseq data, and geometric morphometrics (Argolo et al., 2020) provided support for the eight nominal species of this group and suggested the recognition of an additional two species, increasing the taxonomic diversity of this group by $20 \%$.

\section{The Geophagus sensu stricto species group has received relatively little recent taxonomic} attention. Geophagus sensu stricto includes both broadly distributed species, such as G. altifrons Heckel, 1840 and G. proximus (Castelnau, 1855) and species with restricted distributions such as G. mirabilis Deprá, Kullander, Pavanelli \& da Graça, 2014 endemic to the upper Aripuanã River (upstream of the Dardanelos/Andorinhas rapids) and G. argyrostictus Kullander, 1991occuring in the Belo Monte rapids region of the Xingu River. Many of these species were previously referred to as G. surinamensis (Bloch, 1791; Regan, 1906), but currently these species are part of the G. surinamensis complex (except G. argyrostictus) which contains an undetermined number of undescribed species distributed in the Orinoco and Amazon basins (López-Fernández \& Taphorn, 2004). Several putative species of Geophagus have been proposed for the Amazon basin as well (López-Fernández, 2004; Ohara et al., 2017; Oliveira et al., 2020). 
130 Due to known taxonomic uncertainties in the genus Geophagus (López-Fernández \&

131 Taphorn, 2004; Carvalho et al., 2018; Argolo et al 2020), we produced a COI sequence dataset

132 for the species of the Geophagus sensu stricto species group from the Brazilian Amazon, with

133 the aim (1) to investigate lineage diversity, and (2) to identify species complexes and their

134 distribution patterns. We use the genealogical phylogenetic species concept (Baum and Shaw,

135 2005) to identify lineages (de Queiroz, 2007), and posteriorly we test their morphological

136 distinctness.

137

138 Materials \& Methods

139 Sampling

140 A total of 315 individuals of Geophagus were sampled from 72 localities within the

141 Amazon River basin (Fig. 1; Supplemental Table S1). For each specimen, we collected the right

142 pectoral fin or muscle tissue and preserved it in $96 \%$ ethanol for further laboratory analysis.

143 Vouchers were preserved in 10\% formaldehyde, and subsequently transferred to $70 \%$ ethanol for

144 long-term storage. We obtained samples during field expeditions, from fishermen, local markets,

145 or through tissue collections of the Universidade Federal de Rondônia (UNIR); the

146 Ichthyological Collection of Instituto Nacional de Pesquisas da Amazônia (INPA); and from

147 Animal Genetics Tissue Collection of the Laboratório de Evolução e Genética Animal of the

148 Universidade Federal do Amazonas (CTGA-UFAM). All individuals were captured and sampled

149 under license granted by the Instituto Brasileiro do Meio Ambiente e dos Recursos Naturais

150 Renováveis (IBAMA/SISBIO permit \#62216-1). Collection of organisms was undertaken in

151 accordance with the ethical recommendations of the Conselho Federal de Biologia (CFBio;

152 Federal Council of Biologists), Resolution 301 (December 8, 2012).

153 Morphological Identification

154 For the morphological identification of Geophagus individuals, we used original

155 descriptions and identification keys (Kullander, 1991; López-Fernández \& Taphorn, 2004;

156 Lucinda, Lucena \& Assis, 2010; Deprá et al., 2014). Thus, identified individuals are hereinafter

157 referred to as morpho-species. For those individuals that could not be identified to the species

158 level using the original descriptions and taxonomic keys, the following nomenclature was used: 
159 Geophagus sp. (possible new/unidentified species) (Bengtson, 1988; Sigovini, Keppel \&

160 Tagliapietra, 2016).

161

\section{COI sequence data generation}

163 Genomic DNA was isolated using the phenol-chloroform method (Sambrook, Fritsch \& 164 Maniatis, 1989). DNA integrity was visualized on a $0.8 \%$ agarose gel stained with GelRed 165 (Biotium). Quantification and quality of DNA were checked spectrophotometrically in Nanodrop 1662000 (Thermo-Scientific) and diluted to a final concentration of $50 \mathrm{ng} / \mu 1$.

167

The partial fragment of mitochondrial cytochrome $\mathrm{c}$ oxidase subunit I (COI) was amplified 168 in a $15 \mu \mathrm{l}$ PCR mix containing: $7.6 \mu \mathrm{l}$ of $\mathrm{ddH}_{2} \mathrm{O}, 1.2 \mu \mathrm{dNTP}(10 \mathrm{mM}), 1.5 \mu 1$ buffer $10 \mathrm{X}$ 169 (100mM Tris-HCl, $500 \mathrm{mM} \mathrm{KCl}), 1.2 \mu \mathrm{MgCl}_{2}(25 \mathrm{mM}), 1.2 \mu 1$ of primers COI-Fish-f.2 and 170 COI-Fish-r.1 (2 pM each) (Ivanova et al., 2007), $0.5 \mu$ of Taq DNA polymerase (1U/ $\mu \mathrm{l})$ and $1 \mu \mathrm{L}$ 171 of template DNA (final concentration of $50 \mathrm{ng} / \mu \mathrm{l}$ ). PCR cycling conditions were as follows: 172 denaturation at $93{ }^{\circ} \mathrm{C}$ for 1 minute, 35 cycles of denaturation at $93{ }^{\circ} \mathrm{C}$ for 10 seconds, annealing 173 at $50^{\circ} \mathrm{C}$ for 45 seconds, and extension at $72{ }^{\circ} \mathrm{C}$ for 1 minute, followed by a final extension cycle 174 of $72{ }^{\circ} \mathrm{C}$ for 7 minutes. PCR products were purified using ExoSap and subjected to fluorescent 175 dye-terminator (ddNTP) sequencing following the manufacturer's recommended protocol for 176 BigDye sequencing chemistry (Applied Biosystems). Purified amplicons were sequenced on an 177 automatic ABI 3500 sequencer (Applied Biosystems).

178 The organization, verification, and edition of the sequences were carried out in Geneious 179 software v 7.0.6 (Kearse et al., 2012). The chromatogram reads for each sample sequenced were 180 assembled into contigs and verified visually. We also translated the contigs into putative amino

181

182 183

184 185 186 187 188 189 acids to check for the presence of stop codons; no internal stop codons were found. The alignment tool MAFFT v7.307 (Katoh \& Standley, 2013) was used to perform the alignment which was later edited manually. Twenty two GenBank and BOLD sequences (accession number: Geophagus proximus -FUPR931-09, FUPR932-09, FUPR933-09, FUPR934-09, FUPR935-09, GU701784; G. sveni - MH78091, MK012088; G. harreri -DSFRE369-08; G. argyrostictus- PARO177-08, PARO178-08, PARO179-08, PARO180-08; G. surinamensisKU568829, KU568830, DSFRE196-08, BNAF153-09, BNAF152-09; G. dicrozosterDSFRE170-08, DSFRE171-08, DSFRE138-08; 'Geophagus' steindachneri - KR150866) were added to the alignment, which added five sampling sites outside the Amazon basin, representing 
190 four localities in the Paraná River basin and one in the upper Tocantins River. 'Geophagus' 191 steindachneri (KR150866 and CTGA 145) was used as an outgroup based in the phylogenetic 192 relationship of Geophagines (López-Fernández et al., 2005). Thus, the final dataset comprised 193337 individuals sampled from 77 localities. A Neighbor-Joining tree containing all sequences is 194 provided as Supplemental material (Supplemental Fig. 1). All new sequences generated in this 195 study are available in the GenBank nucleotide file under accessions MZ504295-MZ504609.

196

197 198

199

200

201

202

203

204

205

206

207

208

209

210

211

212

213

214

215

216

217

218

219 Metadata for all sequences used in this study are presented in Supplemental Table S1 as a flat file following the standard Darwin core format (http://rs.tdwg.org/dwc/terms/index.htm).

\section{Species discovery analyses}

For single-locus species discovery (SLSD) analyses, the total dataset was reduced to a new dataset containing unique haplotypes using the hapCollapse function (available at http://github.com/legalLab/protocols-scripts) in the statistical software R (R Development Core Team, 2011). We then generated a Bayesian Inference phylogeny using the software BEAST 2.6.2 (Bouckaert et al., 2019) using the following settings: nucleotide substitution model ( $\operatorname{TrN}+\mathrm{I}$ $+\mathrm{G}$ ) estimated using the BEAST2 package bModelTest 1.2.1 (Bouckaert \& Drummond, 2017); single site model partition; strict molecular clock; Yule model tree prior. We ran three independent runs with 20 million Markov Chain Monte Carlo (MCMC) generations each, sampling tree topologies and parameters every 2,000 generations. The convergence of parameters of each run was observed by checking the values of effective sample size (ESS > 200) and stationarity of the chain using the software TRACER 1.7.1 (Rambaut et al., 2018). We combined the runs, subsampled at a frequency of 6,000 generations, and burned-in the first $10 \%$ generations of each run using LogCombiner (Drummond et al., 2012) to produce a final dataset with 9,000 topologies which were used to produce a maximum credibility tree in TREEANNOTATOR (Bouckaert et al., 2019).

We used the maximum credibility tree as input for four single-locus species discovery analyses: GMYC, the Generalized Mixed Yule Coalescent method (Fujisawa \& Barraclough, 2013); bGMYC, a Bayesian implementation of GMYC (Reid \& Carstens, 2012); mPTP, the multi-rate Poisson tree process method (Kapli et al., 2017); and LocMin, a threshold distance based method (Brown et al., 2012). For GMYC, we used the package splits_1.0-19 (Fujisawa \& 
220 Barraclough, 2013); for bGMYC, we used the package bGMYC 1.0.2 (Reid \& Carstens, 2012).

221 For mPTP, we transformed the BEAST tree into a rooted phylogram using the 'optim.pml'

222 function of phangorn_2.3.1 (Schliep, 2011), optimizing the topology, branch lengths, and gamma

223 rate parameters. The phylogram was used as input into the stand-alone software mptp 0.2.3

224 (Kapli et al., 2017). We also used a p-distance based method using the 'locMin' and 'tclust'

225 functions, a distance threshold optimization and a clustering approach implemented in SPIDER

226 (Brown et al., 2012). All analyses were carried out in the R statistical software v. 3.6.2 (R

227 Development Core Team, 2011) and visualized using the package ggtree (Yu et al., 2017).

\section{Mapping evolutionary lineages}

229

We compared the diversity of lineages of Geophagus sensu stricto with the biogeographic

units proposed for fish in the Amazon basin. To understand the distribution of Geophagus sensu

231 stricto lineages in the Brazilian Amazon basin, we used the bGMYC result obtained from the

232 Single-Locus Species Discovery (SLSD) methods and plotted in the biogeographic units 233 proposed by Dagosta \& De Pinna, 2017 (Supplemental Fig. 2-6), the names of these units are 234 also present in the delimitation tree (Fig. 2). While we did not favor any of the four methods a 235 priori, bGMYC same as MPTP is relatively conservative, but at the same time it also captured 236 common biogeographic patterns (e.g. endemic taxa in the Araguaia-Tocantins basin) and 237 delimited all described species, and therefore we used the bGMYC results for mapping. The 238 visualization of the results has the objective of showing the spatial distribution of lineages, 239 drainages and/or biogeographic units that shelter an elevated diversity of lineages, endemic 240 lineages and those that are distributed in more than one biogeographic unit.

\section{Results}

243 We obtained 315 partial COI sequences of Geophagus from 72 localities in the Amazon

244 basin. The addition of sequence data from GenBank and BOLD increased this dataset to 337

245 specimens from 77 localities inside and outside the Amazon basin. This alignment was then

246 reduced to a total of 125 unique haplotypes from the Geophagus sensu stricto species group plus

247 two 'Geophagus' steindachneri haplotypes as outgroup. Sequence length varied from 317 to 702

248 bp, with a mean sequence length of 644 bp; 183 sites were variable. A total of 16 morpho-

249 species were analyzed (10 nominal and 6 morphologically distinct but undescribed species). The 
250 morpho-species identified to the species level were: G. altifrons Heckel, 1840; G. argyrostictus

251 Kullander, 1991; G. dicrozoster López-Fernández \& Taphorn, 2004; G. harreri Gosse, 1976; G.

252 megasema Heckel, 1840; G. mirabilis Deprá, Kullander, Pavanelli \& da Graça 2014; G.

253 proximus (Castelnau, 1855); G. sveni Lucinda , Lucena \& Assis 2010; G. winemilleri López-

254 Fernández \& Taphorn, 2004 and 'Geophagus' steindachneri (Eigenmann \& Hildebrand, 1922).

255 Candidate species were identified as Geophagus sp. 1 to sp. 6 (Table 1).

256 The number of individuals per morpho-species varied from 1 to 104; haplotypes per

257 morpho-species varied from 1 to 33; the number of drainage basins in which the morpho-species

258 occur varied from 1 to 22 ; the number of sampled localities for each morpho-species varied from

2591 to 39 ; the maximum intraspecific p-distance within morpho-species varied from 0 to $2.3 \%$; the

260 minimum interspecific p-distance between morpho-species varied from 0.6 to $13 \%$. The locMin

261 analysis optimized a divergence threshold of 1.86\% (p-distance) for the dataset. For the 16

262 morpho-species identified a priori, fourteen (87.5\%) were monophyletic and two (12.5\%) were

263 represented by a single haplotype (singleton). The most widely distributed nominal species had

264 the greatest haplotype sharing. In G. proximus 40 individuals shared the same haplotype and $G$.

265 altifrons 34 individuals shared the same haplotype (Fig. 2).

266 The number of species/lineages discovered by each method were 15 (mPTP), 14 (locMin),

26718 (bGMYC), and 30 (GMYC) (Table 1). Species/lineages delimited by all four methods were:

268 Geophagus argyrostictus, G. dicrozoster, G. harreri, G. mirabilis, 'G.' steindachneri, G. sveni,

269 Geophagus sp. 2, Geophagus sp. 4, and Geophagus sp. 6. Three of the four methods (mPTP,

270 LocMin, and bGMYC) delimited Geophagus sp. 3 and Geophagus sp. 5. Two of the four

271 methods delimited G. altifrons (mPTP, LocMin), G. megasema (mPTP, bGMYC), G. proximus

272 (bGMYC, GMYC), and Geophagus sp. 1 (mPTP, bGMYC). The only method to delimit $G$.

273 winemilleri as a species/lineage was bGMYC.

274 The GMYC method indicated several more species/lineages within each clade than the 275 other methods. None of the four methods were able to delimit Geophagus surinamensis and G.

276 proximus sequences obtained from GenBank and BOLD databases as putative species. These

277 sequences were nested within the species Geophagus altifrons and G. sveni, respectively.

278

\section{Discussion}


Our results unambiguously support the monophyly of the Amazonian species of

281 Geophagus. With exception of 'Geophagus' steindachneri - a trans-Andean species and the

282

283

284

285

286

287

288

289

290

291

292

293

294

295

296

297

298

299

300

301

302

303

304

305

306

307

308

outgroup of our analyses - all the morpho-species sampled in this study belong to the Geophagus sensu stricto species group and were highly supported as monophyletic. The monophyly of the sensu stricto species group has been demonstrated elsewhere (Farias et al., 1999; Farias, Ortí \& Meyer, 2000; López-Fernández, Honeycutt \& Winemiller, 2005; Smith, Chakrabartyb \& Sparks, 2008), but relationships between all nominal species in this group have not yet been resolved.

After extensive sampling in the main channel of the Amazon basin and in most of its tributaries, our analysis covered a total of 10 nominal species of Geophagus out of a total of 20 species described for the sensu stricto species group. Additionally, we identified six candidate species that could not be assigned to any other species of the Geophagus sensu stricto species group after the usage of original keys and descriptions of the species of the genus. The phylogenetic reconstruction and the SLSD methods delimited all six candidate species as independent and reciprocally monophyletic lineages (Fig. 2).

The maximum credibility tree recovered a highly supported clade containing six nominal species of the Geophagus surinamensis "complex" of López-Fernández \& Taphorn (2004) (Fig. 2). The phylogenetic position of G. dicrozoster, however, was not fully resolved. Although this species is sister to the G. surinamensis "complex", this placement has low posterior probability support and is best interpreted as a polytomy which also includes the highly supported $G$.

argyrostictus clade, comprised of G. argyrostictus, Geophagus sp. 4 and Geophagus sp. 5. At the base of the tree, the position of G. harreri was uncertain and had low posterior support. The species of Geophagus sensu stricto closest to 'G.' steindachneri, outgroup in our analyses, was Geophagus sp. 6 from Azul River, a tributary of Teles Pires River.

\section{Unrecognized and misrepresented diversity}

Our results show high diversity of Geophagus within the Amazon basin. The most conservative SLSD method (mPTP) indicates 15 species/lineages and the least conservative method (GMYC), 30 species/lineages (including 'Geophagus' steindachneri). This last method usually tends to perform poorly and oversplits lineages when effective population sizes $(\mathrm{Ne})$ and speciation rates are high (Fujisawa \& Barraclough, 2013; Dellicour \& Flot, 2018). Population

Peer) reviewing PDF | (2021:06:63116:1:0:NEW 7 Oct 2021) 
309 structure and low sampling effort also affect results (Papadopoulou et al., 2008; Lohse, 2009),

310 although it does not invalidate the method per se (Papadopoulou et al., 2009).

311 The vast majority of these species/lineages inhabit tributaries instead of the main channel

312 of the Amazon River (Supplemental Fig. 6). We found five of the six undescribed species

313 occurring only in the tributaries, being restricted to one or few water bodies: Geophagus sp. 2

314 (Purus), Geophagus sp. 3 (Xingu), Geophagus sp. 4 (Tapajos), Geophagus sp. 5 (Madeira and

315 Tapajos), and Geophagus sp. 6 (Teles Pires). The undescribed species Geophagus sp. 1 occurs in

316 multiple tributaries (Branco, Japura, Jari, Madeira, Negro, Tapajos, Trombetas, and Xingu) and

317 is also found in the main channel of the Amazon River.

318

The two and three individuals deposited in Genbank and BOLD under the epithet

319 Geophagus surinamensis have common haplotypes of the geographically widespread $G$.

320 altifrons. Given that either no vouchers exist or that the specimens are from "petshop" and of

321 unknown geographic origin, and that G. surinamensis and G. altifrons are differentiated by

322 subtle morphological differences (Soares et al. 2008), we considered these five samples

323 misidentified G. altifrons.

324

The sequences in GenBank of individuals from the Paraná River basin identified as $G$.

325

"proximus" (5) and as G. sveni from Paraná River basin and the Tocantins River (2) were

326 delimited by the four methods as a clade (Fig. 2). Benitez et al. (2018) found minimal or no

327 genetic divergence between these individuals and suggested that all specimens were $G$. sveni

328 misidentified as G. "proximus". Furthermore, specimens collected in the Paraná River basin and initially identified as G. cf. proximus (Graça \& Pavanelli, 2007; Sampaio \& Goulart, 2011) were later reassigned to G. sveni (Ota et al., 2018). These species share characteristics such as the presence of prominent mid-lateral black markings and absence of a complete infraorbital stripe, but differ in the markings in the preopercle, which is present in G. proximus and absent in $G$. sveni. Although these species also differ in the lateral bars that are present in G. sveni (Lucinda,

334 Lucena \& Assis, 2010) and absent in G. proximus (López-Fernández \& Taphorn, 2004) in 335 preserved specimens, discrimination of live individuals is not trivial. Both G. proximus and $G$. sveni are invasive species in the Paraná-Paraguay River basin, and their occurrence may be associated with the aquarium trade (Gois et al., 2015; Ota et al., 2018). 
339 the Geophagus sp. 1 clade. Several individuals of this clade (posterior probability $=0.999$ ) were 340 incorrectly identified by their collectors during field expeditions as Geophagus cf. winemilleri

341 (21 individuals), Geophagus winemilleri (6 individuals), Geophagus cf. abalios (5 individuals),

342 Geophagus aff. winemilleri (4 individuals), Geophagus aff. altifrons (4 individuals), Geophagus

343 dicrozoster (2 individuals), Geophagus abalios, (1 individual), Geophagus cf. altifrons (1

344 individual), Geophagus megasema (1 individual) and 12 more individuals identified as

345 Geophagus sp. (Tapajós-Xingu) totaling 57 questionably identified individuals. All individuals

346 of this clade possess five ventrally-inclined lateral bars, the first four being bisected by a clearer 347 area, giving the appearance of two thinner bars, (as in G. abalios) - and the last one solid; the 348 presence of midlateral spot (MLS) located in the third lateral bar; absence of infraorbital stripe 349 (IOS); and absence of preopercular marks (POM). This combination of characters does not 350 match character states of any nominal species, and therefore we classified these specimens as 351 Geophagus sp. 1. Geophagus sp. 1 is also the third species - in addition to G. altifrons and G. 352 proximus - to have a basin-wide distribution.

353 During reexamination of collected specimens, using either preserved specimens and/or 354 photographs of the live specimens collected in the field, we also observed that both G. altifrons 355 and G. proximus appear to be treated as "default species" by their collectors. Many incorrect 356 identifications have been attributed to these two species, perhaps because they are the most 357 abundant and widely distributed species and/or the collection site was taken into account for 358 species assignment.

359

\section{Geographic distribution of Geophagus lineages}

The geographic distribution of the Geophagus sensu stricto lineages found in this study adds a new layer of complexity to understanding the evolutionary history of this species group in the Amazon basin. There are widely spread lineages in the Amazon River and its tributaries $(G$. altifrons sensu stricto, G. proximus sensu stricto, and the Geophagus sp. 1), lineages occurring in one or few tributaries (G. altifrons Araguaia-Tocantins, G. megasema, G. winemilleri and 
367 argyrostictus, G. mirabilis, G. proximus Purus, Geophagus sp. 2, Geophagus sp. 3, Geophagus 368 sp. 4, Geophagus sp. 6 and Geophagus sveni) (Fig. 1).

369 Within the two broadly distributed described species, we delimited two lineages of $G$. 370 altifrons (Supplemental Fig. 2) and two lineages of G. proximus (Supplemental Fig. 3). In both 371 species, one lineage was restricted to the Araguaia-Tocantins River basin and the other to the 372 lower Purus River basin, respectively. The third widely distributed species (Geophagus sp. 1) 373 appears to be a single lineage (Supplemental Fig. 4).

$374 \quad$ Geophagus altifrons is a species with an eastern Amazon distribution pattern according to 375 Dagosta \& De Pinna (2019). While most of our samples and collecting sites of both lineages of 376 G. altifrons were to the east of the Purus Arch and thus would appear to be concordant with the 377 hypothesis of Dagosta \& De Pinna (2019) that the Purus Arch limits the distribution of $G$.

378 altifrons to the east, G. altifrons sensu stricto also occurs in the Japura River, a western tributary 379 of the Amazon, an indication that the Purus Arch did not limit its distribution.

380 Kullander $(1986,2003)$ proposed that G. proximus occurs along the Ucayali-Solimões381 Amazonas River to at least the Trombetas River. Dagosta \& De Pinna (2019) report an even 382 wider distribution for the species, including drainages of the Araguaia-Tocantins, Xingu, 383 Madeira, Purus, Tefé, Ucayali, Japura, Negro, Branco, and Trombetas river basins, i.e. extending 384 the distribution of G. proximus to the mouth of the Amazon River and affluents. We are unable 385 to confirm this broader distribution proposed by Dagosta \& De Pinna (2019) since we detected 386 G. proximus from the Jurua River east to the Tapajos River - the Tapajos River is a southern 387 affluent of the Amazon shortly after its confluence with the Trombetas River. We also found a 388 distinct lineage of G. proximus delimited by both GMYC and bGMYC methods (Fig. 2) that 389 occurs in the middle Purus River (G. proximus Purus).

Geophagus megasema was found in the Madeira River basin downstream to Manicoré 391 (Supplemental Fig. 5). Three individuals from Ipixuna River - a middle Purus River tributary 392 that at its headwaters is connected to the Madeira River - which were morphologically identified 393 as G. cf. altifrons in the field - were nested within the G. megasema clade. There were also five 394 individuals from Mamirauá Sustainable Development Reserve that were included within this 395 clade. Kullander (2003) reports the distribution of the species in the Guapore River basin. 396 Dagosta \& De Pinna (2019) extends its distribution to the Beni-Madre de Dios River basin in 397 Bolivia, the middle and lower Madeira River, and Japura River basin. Our results agree with this 
398 proposed distribution and extend the distribution of G. megasema to at least the middle Purus

399 River. This sharing of fish fauna between these two basins was reported in the Madeira-Purus 400 interfluvial checklist (Barros et al., 2011, 2013).

401 Geophagus winemilleri was delimited by two methods (bGMYC and GMYC) as lineages 402 different from G. proximus. Geophagus winemilleri has a known distribution in the Negro and 403 Orinoco river basins (López-Fernández \& Taphorn, 2004), but we have detected this species in 404 the Branco River as well (Supplemental Fig. 5). Despite the geomorphological and the physical405 chemical differences between these rivers, other studies have already demonstrated the sharing 406 of the ichthyofauna between them (Dagosta \& De Pinna, 2019).

407 The lineage Geophagus sp. 5 occurs in the clear water rivers of the Aripuana, Machado, 408 and lower Tapajos (Supplemental Fig. 6). Madeira and Tapajos are neighboring basins and both 409 Aripuana and Machado are tributaries of the Madeira River that drain the Brazilian shield. There 410 are several records of faunal sharing between these basins, mostly between the Aripuana, 411 Guapore, and Machado rivers with the Juruena River, a Tapajós River tributary (Dagosta \& De 412 Pinna, 2019). The sharing of ichthyofauna between these basins can be mostly explained by 413 geomorphological processes that resulted in stream capture events across the Madeira-Tapajos 414 interfluvial, which in turn resulted in geodispersal of entire faunas (Dagosta \& De Pinna, 2019).

415 The endemic species G. argyrostictus was sampled in the Iriri and Xingu rivers 416 (Supplemental Fig. 6). The species is only known from the upper and middle reaches of the 417 Xingu River (Kullander, 1991), although the individuals of the upper Xingu (Cachoeira von 418 Martius) analyzed by Kullander (1991) differ slightly from the middle Xingu (Altamira, Belo 419 Monte, and Cachoeira do Espelho) in morphometric measurements and in average counts of gill 420 rakers, pectoral fin rays, and abdominal vertebrae. However, we have no data to either confirm 421 or to reject that the specimens from the upper and middle Xingu River represent distinct lineages. 422 Kullander (1991) also states that the only other Geophagus species in the Xingu River is G. 423 altifrons, which is sympatric with G. argyrostictus. However, in addition to G. argyrostictus and 424 G. altifrons our results suggest the occurrence of two other lineages in the Xingu River basin: 425 Geophagus sp.1, the broadly distributed species which occurs in the lower Xingu River, and 426 Geophagus sp. 3 an apparent endemic of the middle Xingu region (Fig. 1). Geophagus sp. 3 also 427 occurs in the Iriri and Bacaja rivers, both tributaries of the middle Xingu River. 
Geophagus mirabilis was found at a single locality in the Aripuana River, downstream of 429 the Dardanelos falls, and G. sveni was collected only in the upper Tocantins River. Both rivers 430 are recognized for having a large number of endemic species (Lucinda, Lucena \& Assis, 2010; 431 Deprá et al., 2014).

432 The lineage Geophagus sp. 2 occurs only in the Purus River (Supplemental Fig. 6). The 433 upper Purus River has already been recognized in several studies as a region that possesses 434 structured fish populations, and events in the historical biogeography of this region, such as the 435 elevation of the Fitzcarrald Arch and drainage captures are suggested as responsible for these 436 structured populations (Machado et al., 2017; Santos, Hrbek \& Farias, 2018). Geophagus sp. 4 437 was found only in the region of Vila Pimental, Tapajos River, and Geophagus sp. 6 was found 438 occurring only in the Azul River, a tributary of the Teles Pires River (Supplemental Fig. 6).

439 Tapajós and Xingu rivers are recognized for elevated levels of ichthyofaunal endemism

440 (Fitzgerald et al., 2018; Oberdorff et al., 2019). Recent studies have only increased the number of 441 endemics in these basins (Silva-Oliveira, Canto \& Ribeiro, 2015, 2016; Carvalho, 2016;

442 Fitzgerald et al., 2018).

443

\section{Implications for conservation}

445 The discovery of possible new species of cichlid fishes in the Amazon basin is yet 446 another example of how little we know of the biodiversity around us. Lineages are products of 447 evolutionary processes (De Queiroz, 2007). When conserving these lineages, the processes 448 which generated them are also conserved (Coates, Byrne \& Moritz, 2018; Hrbek et al., 2018). 449 Floodplains, rapids, and waterfalls are in constant threat due to human activities (Castello et al., 450 2013; Castello \& Macedo, 2016). When these areas are permanently altered by humans, not only 451 ichthyofaunal diversity is lost, but the entire evolutionary history recorded in these species is lost 452 as well, hindering our efforts to understand the processes that generated the astonishing diversity 453 of Amazonian fishes. Habitat destruction, deforestation, mining, and hydroelectric dam 454 construction are examples of human activities that harm both hydrological connectivity and 455 ecosystem services (Castello et al., 2013; Castello \& Macedo, 2016).

456 Many of the new lineages discovered in our study were found in areas near rapids or 457 waterfalls - environments commonly preferred for the construction of hydroelectric dams 
458 (Winemiller et al., 2016). One example is the candidate species Geophagus sp 4. which was

459 found only in the Tapajós River, in the region of Vila Pimental, location planned for the 460 construction of the São Luiz do Tapajós hydroelectric plant. The construction and filling of the 461 dam leads to the disappearance of these environments. Therefore, the endemic species sheltered 462 in these singular environments may disappear if the areas in which they occur are permanently 463 altered. Thus, the recognition of these lineages as conservation dependent is important to guide 464 conservation actions in these impacted areas and to direct efforts to the formal examination of 465 these lineages as putative species, which could already be threatened or in danger of extinction.

466

\section{Conclusions}

The results of the single locus species delimitation methods complemented morphological delimitations; all six morphospecies identified in this study were also delimited as species/lineages, and all described species with the exception of $G$. winemilleri and G. proximus

471 in the case of mPTP and bGMYC, were delimited as lineages or clusters of species. These results 472 therefore provide strong and consistent evidence for additional taxonomic diversity in this group. 473 Although not formally described in this study, these six new species increase the taxonomic 474 diversity of Geophagus sensu stricto by $30 \%$. Of the six new species, five are endemic or inhabit 475 areas subject to major human threats. Our sampling was not exhaustive, however, and we expect 476 that additional species will be discovered principally in poorly sampled regions of the Amazon 477 basin.

\section{Acknowledgements}

We are grateful to all the volunteers/colleagues who collected field samples and who for 481 years have contributed to the tissue collection (CTGA/UFAM). We especially thank Joiciane 482 Farias, Natasha Meliciano, Mário Nunes, Rupert Collins, Daniel Toffoli, Stuart Willis, and 483 Hernán López for their help with field collection, Carolina Doria (Universidade Federal de 484 Rondônia-UNIR, Coleção de tecidos do laboratório de Ictiologia e Pesca), Camila Ribas 485 (Instituto Nacional de Pesquisas da Amazônia-INPA, Coleção de Recursos Genéticos Animais), 486 Lúcia Py-Daniel (INPA, Coleção Ictiológica) for the tissue samples from the ichthyological 
487 collections. This study is part of AMX's doctoral dissertation in the Genetics, Conservation and

488 Evolutionary Biology graduate program INPA/UFAM.

489

490 References

491

492

493

494

495

496

497

498

499

500

501

502

503

504

505

506

507

508

509

510

511

512

513

514

515

516

517

518

519

520

521

522

523

524

525

526

527

528

529

Alves-Silva AP, Dergam JA. 2014. Cryptic speciation within the Neotropical cichlid Geophagus brasiliensis (Quoy \& Gaimard, 1824) (Teleostei Cichlidae): A new paradigm in Karyotypical and Molecular Evolution. Zebrafish 00:1-6. DOI: 10.1089/zeb.2014.0999.

Amado MV, Farias IP, Hrbek T. 2011. A molecular perspective on systematics, taxonomy and classification amazonian discus fishes of the genus Symphysodon. International Journal of Evolutionary Biology 2011:1-16. DOI: 10.4061/2011/360654.

Amaral CRL, Brito PM, Silva DA, Carvalho EF. 2013. A new cryptic species of South American freshwater pufferfish of the genus Colomesus (Tetraodontidae), based on both morphology and DNA data. PloS one 8:1-15. DOI: 10.1371/journal.pone.0074397.

Argolo LA, López-Fernández H, Batalha-Filho H, Affonso PRAM. 2020. Unraveling the systematics and evolution of the "Geophagus" brasiliensis (Cichliformes: Cichlidae) species complex. Molecular Phylogenetics and Evolution 150:1-12. DOI: 10.1016/j.ympev.2020.106855.

Arruda PSS, Ferreira DC, Oliveira C, Venere PC. 2019. DNA Barcoding reveals high levels of divergence among mitochondrial lineages of Brycon (Characiformes, Bryconidae). Genes 10:1-12. DOI: 10.3390/genes10090639.

Barros D, Albernaz A, Zuanon J, Espírito Santo H, Mendonça F, Galuch A. 2013. Effects of isolation and environmental variables on fish community structure in the Brazilian Amazon Madeira-Purus interfluve. Brazilian Journal of Biology 73:491-499. DOI: 10.1590/s151969842013000300005.

Barros DF, Zuanon J, Mendonça FP, Santo HMVE, Galuch AV, Albernaz ALM. 2011. The fish fauna of streams in the Madeira-Purus interfluvial region, Brazilian Amazon. Check List 7:768-773. DOI: $10.15560 / 11022$.

Bengtson P. 1988. Open Nomenclature. Palaentology 31:223-227. DOI: 10.4039/Ent8431-1.

Benitez MF, Cerutti JC, Aichino DR, Baldo D. 2018. Morphological and molecular identification of Geophagus sveni Lucinda, Lucena \& Assis, 2010 (Cichlidae, Cichliformes) from the Paraná river basin, Argentina. Check List 2010:1053-1058. DOI: 10.15560/14.6.1058.

Bloom DD, Lovejoy NR. 2017. On the origins of marine-derived freshwater fishes in South America. Journal of Biogeography 44:1927-1938. DOI: 10.1111/jbi.12954.

Bouckaert RR, Drummond AJ. 2017. bModelTest: Bayesian phylogenetic site model averaging and model comparison. BMC Evolutionary Biology 17:1-11. DOI: 10.1186/s12862-0170890-6.

Bouckaert R, Vaughan TG, Barido-Sottani J, Duchêne S, Fourment M, Gavryushkina A, Heled J, Jones G, Kuhnert D, Maio N De, Matschiner M, Mendes F, Muller NF, Ogilvie HA, Plessis L du, Popinga A, Rambaut A, Rasmussen D, Siveroni I, Suchard MA, Wu C, Xie D, Zhang C, Stadler T, Drummond AJ. 2019. BEAST 2.5: An advanced software platform for Bayesian evolutionary analysis. PLoS Computational Biology 15:1-28. DOI: 10.1371/journal.pcbi.1006650. 
530 Brown SDJ, Collins RA, Boyer S, Lefort MC, Malumbres-Olarte J, Vink CJ, Cruickshank RH.

531

532

533

534

535

536

537

538

539

540

541

542

543

544

545

546

547

548

549

550

551

552

553

554

555

556

557

558

559

560

561

562

563

564

565

566

567

568

569

570

571

572

573

574

575
2012. Spider: An R package for the analysis of species identity and evolution, with particular reference to DNA barcoding. Molecular Ecology Resources 12:562-565. DOI: 10.1111/j.1755-0998.2011.03108.x.

Carvalho MR. 2016. Description of two extraordinary new species of freshwater stingrays of the genus Potamotrygon endemic to the rio Tapajós basin, Brazil (Chondrichthyes: Potamotrygonidae), with notes on other Tapajós stingrays. Zootaxa 4167:1-63. DOI: doi.org/10.11646/zootaxa.4167.1.1.

Carvalho APC, Collins RA, Martínez JG, Farias IP, Hrbek T. 2018. From shallow to deep divergences: mixed messages from Amazon Basin cichlids. Hydrobiologia 832:317-329. DOI: $10.1007 / \mathrm{s} 10750-018-3790-\mathrm{x}$.

Carvalho DC, Oliveira DAA, Pompeu PS, Leal CG, Oliveira C, Hanner R. 2011. Deep barcode divergence in Brazilian freshwater fishes:The case of the São Francisco River basin. Mitochondrial DNA 22:80-86. DOI: 10.3109/19401736.2011.588214.

Castello L, Macedo MN. 2016. Large-scale degradation of Amazonian freshwater ecosystems. Global Change Biology 22:990-1007. DOI: 10.1111/gcb.13173.

Castello L, Mcgrath DG, Hess LL, Coe MT, Lefebvre PA, Petry P, Macedo MN, Renó VF, Arantes CC. 2013. The vulnerability of Amazon freshwater ecosystems. Conservation Letters 6:217-229. DOI: 10.1111/conl.12008.

Castelnau F. 1855. Animaux nouveaux or rares recueillis pendant l'expédition Dans les parties centrales de L'amérique du Sud, de Rio de Janeiro a Lima, et de Lima au Para. Annalen des Wiener Museums der Naturgeschichte 2:1-112. DOI: 6326567\#page/688/mode/1up.

Coates DJ, Byrne M, Moritz C. 2018. Genetic diversity and conservation units: Dealing with the species-population continuum in the age of genomics. Frontiers in Ecology and Evolution 6:1-13. DOI: 10.3389/fevo.2018.00165.

Colatreli OP, Meliciano NV, Toffoli D, Farias IP, Hrbek T. 2012. Deep phylogenetic divergence and lack of taxonomic concordance in species of Astronotus (Cichlidae). International Journal of Evolutionary Biology 2012:1-8. DOI: 10.1155/2012/915265.

Collins RA, Bifi AG, Oliveira RR De, Ribeiro ED, Lujan NK, Py-daniel LHR, Hrbek T. 2018. Biogeography and species delimitation of the rheophilic suckermouth catfish genus Pseudolithoxus (Siluriformes: Loricariidae), with the description of a new species from the Brazilian Amazon. Systematics and Biodiversity 15:1-13. DOI: 10.1080/14772000.2018.1468362.

Dagosta FCP, De Pinna M. 2017. Biogeography of Amazonian fishes: Deconstructing river basins as biogeographic units. Neotropical Ichthyology 15:1-24. DOI: 10.1590/1982-022420170034.

Dagosta FCP, De Pinna M. 2018. A history of the biogeography of Amazonian fishes. Neotropical Ichthyology 16:1-19. DOI: 10.1590/1982-0224-20180023.

Dagosta FCP, De Pinna M. 2019. The fishes of the Amazon: Distribution and biogeographical patterns, with a comprehensive list of species. Bulletin of the American Museum of Natural History 413:1-163. DOI: 1206/0003-0090.431.1.1.

Dellicour S, Flot JF. 2018. The hitchhiker's guide to single-locus species delimitation. Molecular Ecology Resources 18:1234-1246. DOI: 10.1111/1755-0998.12908.

Deprá GC, Kullander SO, Pavanelli CS, Da Graça WJ. 2014. A new colorful species of Geophagus (Teleostei: Cichlidae), endemic to the rio Aripuanã in the Amazon basin of Brazil. Neotropical Ichthyology 12:737-746. DOI: 10.1590/1982-0224-20140038.

Peer] reviewing PDF | (2021:06:63116:1:0:NEW 7 Oct 2021) 
576

577

578

579

580

581

582

583

584

585

586

587

588

589

590

591

592

593

594

595

596

597

598

599

600

601

602

603

604

605

606

607

608

609

610

611

612

613

614

615

616

617

618

619

620

621

De Queiroz K. 2007. Species concepts and species delimitation. Systematic Biology 56:879886. DOI: $10.1080 / 10635150701701083$.

Drummond AJ, Suchard MA, Xie D, Rambaut A. 2012. Bayesian Phylogenetics with BEAUti and the BEAST 1.7. Molecular Biology and Evolution 29:1969-1973. DOI:

10.1093/molbev/mss075.

Farias IP, Hrbek T. 2008. Patterns of diversification in the discus fishes (Symphysodon spp. Cichlidae) of the Amazon basin. Molecular Phylogenetics and Evolution 49:32-43. DOI: 10.1016/j.ympev.2008.05.033.

Farias IP, Ortí G, Meyer A. 2000. Total evidence: molecules, morphology, and the phylogenetics of cichlid fishes. Journal of Experimental Zoology 288:76-92. DOI: 10.1002/(SICI)1097010X(20000415)288:1<76::AID-JEZ8>3.0.CO;2-P.

Farias I, Ortí G, Sampaio I, Schneider H. 1999. Mitochondrial DNA phylogeny of the family Cichlidae: monophyly and fast molecular evolution of the Neotropical assemblage. Journal of Molecular Evolution 48:703-711. DOI: 10.1007/p100006514.

Farias IP, Willis SC, Leão AS de A, Verba JT, Crossa M, Foresti F, Porto-Foresti F, Sampaio I, Hrbek T. 2019. The largest fish in the world's biggest river: genetic connectivity and conservation of Arapaima gigas in the Amazon and Araguaia-Tocantins drainages. PLoS ONE 14:1-27. DOI: 10.1371/journal.pone.0220882.

Fitzgerald DB, Sabaj Perez MH, Sousa LM, Gonçalves AP, Rapp Py-Daniel L, Lujan NK, Zuanon J, Winemiller KO, Lundberg JG. 2018. Diversity and community structure of rapids-dwelling fishes of the Xingu River: Implications for conservation amid large-scale hydroelectric development. Biological Conservation 222:104-112. DOI: 10.1016/j.biocon.2018.04.002.

Flausino-Junior N, Machado FA, Zuanon JS, Ferreira EJ. 2016. The fish fauna of sessile hydrophytes stands (Mourera spp.: Podostemaceae) in the Dardanelos Waterfalls, Rio Aripuanã, Brazil. Aqua, International Journal of Ichthyology 22:133-144.

Fricke R, Eschmeyer WN, Van der Lann R. 2020.Species by family/Subfamily. CAS: Catalog of Fishes. DOI: 10.1017/CBO9781107415324.004.

Fujisawa T, Barraclough TG. 2013. Delimiting species using single-locus data and the generalized mixed yule coalescent approach: A revised method and evaluation on simulated data sets. Systematic Biology 62:707-724. DOI: 10.1093/sysbio/syt033.

Gois KS, Pelicice FM, Gomes LC, Agostinho AA. 2015. Invasion of an Amazonian cichlid in the Upper Parana River : facilitation by dams and decline of a phylogenetically related species. Hydrobiologia 746:401-413. DOI: 10.1007/s10750-014-2061-8.

Graça WJ, Pavanelli CS. 2007. Peixes da planície de inundação do alto rio Paraná e áreas adjacentes. Maringá: Eduem.

Gregory-Bogotá JD, Lima FCT, Correa SB, Oliveira CS, Jenkins DG, Ribeiro FR, Lovejoy NR, Reis RE, Crampton WGR. 2020. Biogeochemical water type influences community composition, species richness, and biomass in megadiverse Amazonian fish assemblages. Scientific Reports 10:1-15. DOI: 10.1038/s41598-020-72349-0.

Hajibabaei M, Singer GAC, Hebert PDN, Hickey DA. 2007. DNA barcoding: how it complements taxonomy, molecular phylogenetics and population genetics. Trends in Genetics 23:167-172. DOI: 10.1016/j.tig.2007.02.001.

Hebert PDN, Ratnasingham S, DeWaard JR. 2003. Barcoding animal life: cytochrome c oxidase subunit 1 divergences among closely related species. The Royal Society 1:96-99. DOI: 10.1098/rsbl.2003.0025.

Peer) reviewing PDF | (2021:06:63116:1:0:NEW 7 Oct 2021) 
622

623

624

625

626

627

628

629

630

631

632

633

634

635

636

637

638

639

640

641

642

643

644

645

646

647

648

649

650

651

652

653

654

655

656

657

658

659

660

661

662

663

664

665

666

667

Heckel J. 1840. Johann Natterer's neue Flussfische Brasilien's nach den Beobachtungen und Mittheilungen des Entdeckers beschrieben (Erste Abtheilung, Die Labroiden). Annalen des Wiener Museums der Naturgeschichte 2:49-85.

Hrbek T, Da Silva VMF, Dutra N, Gravena W, Martin AR, Farias IP. 2014. A new species of river dolphin from Brazil or: How little do we know our biodiversity. PLoS ONE 9:1-12. DOI: 10.1371 journal.pone.0083623.

Hrbek T, Meliciano N V, Zuanon J, Farias IP. 2018. Remarkable geographic structuring of rheophilic fishes of the lower Araguaia River. Frontiers in Genetics 9:1-12. DOI: 10.3389/fgene.2018.00295.

Hubert N, Renno JF. 2006. Historical biogeography of South American freshwater fishes. Journal of Biogeography 33:1414-1436. DOI: 10.1111/j.1365-2699.2006.01518.x.

Ilves KL, Torti D, López-Fernández H. 2018. Exon-based phylogenomics strengthens the phylogeny of Neotropical cichlids and identifies remaining conflicting clades (Cichliformes: Cichlidae: Cichlinae). Molecular Phylogenetics and Evolution 118:232-243. DOI: 10.1016/j.ympev.2017.10.008.

Ivanova N V, Zemlak TS, Hanner RH, Hebert PD. 2007. Universal primer cocktails for fish DNA barcoding. Molecular Ecology Notes 7:544-548. DOI: 10.1111/j.14718286.2007.01748.x.

Kapli P, Lutteropp S, Zhang J, Kobert K, Pavlidis P, Stamatakis A, Flouri T. 2017. Multi-rate Poisson tree processes for single-locus species delimitation under maximum likelihood and Markov chain Monte Carlo. Bioinformatics 33:1630-1638. DOI: 10.1093/bioinformatics/btx025.

Katoh K, Standley DM. 2013. MAFFT Multiple Sequence Alignment Software Version 7: Improvements in Performance and Usability. Molecular Biology and Evolution 30:772-780. DOI: $10.1093 / \mathrm{molbev} / \mathrm{mst} 010$.

Kearse M, Moir R, Wilson A, Stones-havas S, Sturrock S, Buxton S, Cooper A, Markowitz S, Duran C, Thierer T, Ashton B, Meintjes P, Drummond A. 2012. Geneious Basic: An integrated and extendable desktop software platform for the organization and analysis of sequence data. Bioinformatics 28:1647-1649. DOI: 10.1093/bioinformatics/bts199.

Kullander SO. 1986. Cichlid fishes of the Amazon River drainage of Peru. Copeia 4:1078-1080. DOI: 14-12-2015 04:49.

Kullander SO. 1991. Geophagus argyrostictus, a new species of cichlid fish from the rio Xingu, Brazil. Cybium 15:129-138.

Kullander SO. 1998. A phylogeny and classification of the South American Cichlidae (Teleostei: Perciformes). In: Malabarba LR, Reis RE, Vari RP, Lucena CAS eds. Phylogeny and classification of Neotropical fishes. Porto Alegre: Edipucrs, 461-498.

Kullander SO. 2003. Family Cichlidae. In: Roberto E. Reis, Sven O. Kullander, Carl J. Ferraris J ed. Check List of the Freshwater Fishes of South and Central America. Porto Alegre: Edipucrs, 605-654.

Lohse K. 2009. Can mtDNA barcodes be used to delimit species? A response to Pons et al.(2006). Systematic biology 58:439-44. DOI 10.1093/sysbio/syp039.

López-Fernández H, Honeycutt RL, Winemiller KO. 2005. Molecular phylogeny and evidence for an adaptive radiation of Geophagine cichlids from South America (Perciformes: Labroidei). Molecular Phylogenetics and Evolution 34:227-244. DOI: 10.1016/j.ympev.2004.09.004.

López-Fernández H, Taphorn DC. 2004. Geophagus abalios, G. dicrozoster and G. winemilleri

Peer) reviewing PDF | (2021:06:63116:1:0:NEW 7 Oct 2021) 
668

669

670

671

672

673

674

675

676

677

678

679

680

681

682

683

684

685

686

687

688

689

690

691

692

693

694

695

696

697

698

699

700

701

702

703

704

705

706

707

708

709

710

711

712

713
(Perciformes: Cichlidae), three new species from Venezuela. Zootaxa 439:1. DOI: 10.11646/zootaxa.439.1.1.

López-Fernández H, Winemiller KO, Honeycutt RL. 2010. Molecular Phylogenetics and Evolution Multilocus phylogeny and rapid radiations in Neotropical cichlid fishes ( Perciformes: Cichlidae: Cichlinae). Molecular Phylogenetics and Evolution 55:1070-1086. DOI: 10.1016/j.ympev.2010.02.020.

Lovejoy NR, Albert JS, Crampton WGR. 2006. Miocene marine incursions and marine/freshwater transitions: Evidence from Neotropical fishes. Journal of South American Earth Sciences 21:5-13. DOI: 10.1016/j.jsames.2005.07.009.

Lucinda PHF, Lucena CAS, Assis NC. 2010. Two new species of cichlid fish genus Geophagus Heckel from the Rio Tocantins drainage (Perciformes: Cichlidae). Zootaxa 2429:29-42. DOI: 10.11646/zootaxa.2429.1.2.

Machado VN, Collins RA, Ota RP, Andrade MC, Farias IP, Hrbek T. 2018. One thousand DNA barcodes of piranhas and pacus reveal geographic structure and unrecognised diversity in the Amazon. Scientific Reports 8:1-12. DOI: 10.1038/s41598-018-26550-x.

Machado VN, Willis SC, Teixeira AS, Hrbek T, Farias IP. 2017. Population genetic structure of the Amazonian black flannelmouth characin (Characiformes, Prochilodontidae: Prochilodus nigricans Spix \& Agassiz, 1829): contemporary and historical gene flow of a migratory and abundant fishery species. Environmental Biology of Fishes 100:1-16. DOI: 10.1007/s10641-016-0547-0.

Mateussi NTB, Melo BF, Foresti F, Oliveira C. 2019. Molecular data reveal multiple lineages in piranhas of the genus Pygocentrus (Teleostei, Characiformes). Genes 10:1-18. DOI: $10.3390 /$ genes 10050371 .

Mattos JLO, Costa WJEM, Santos ACA. 2015. Geophagus diamantinensis, a new species of the G. brasiliensis species group from Chapada Diamantina, north-eastern Brazil (Cichlidae: Geophagini). Ichthyological Exploration of Freshwaters 26(3): 209-220. Mattos JLO, Costa WJEM. 2018. Three new species of the ' Geophagus ' brasiliensis species group from the northeast Brazil (Cichlidae, Geophagini). Zoosystematics and Evolution 94 (2): 325-337: 329-332. DOI: 10.3897/zse.94.22685.

Melo BF, Sidlauskas BL, Near TJ, Roxo FF, Ghezelayagh A, Ochoa LE, Stiassny MLJ, Arroyave J, Chang J, Faircloth BC, MacGuigan DJ, Harrington RC, Benine RC, Burns MD, Hoekzema K, Sanches NC, Maldonado-Ocampo JA, Castro RMC, Foresti F, Alfaro ME, Oliveir C. 2021. Accelerated diversification explains the exceptional species richness of tropical Characoid fishes. Systematic Biology 40:1-53. DOI: 10.1093/sysbio/syab040.

Monaghan MT, Wild R, Elliot M, Fujisawa T, Balke M, Inward DJG, Lees DC, Ranaivosolo R, Eggleton P, Barraclough TG, Vogler AP. 2009. Accelerated species inventory on Madagascar using coalescent-based models of species delineation. Systematic Biology 58:298-311. DOI: 10.1093/sysbio/syp027.

Montoya-Burgos JI. 2003. Historical biogeography of the catfish genus Hypostomus (Siluriformes: Loricariidae), with implications on the diversification of Neotropical ichthyofauna. Molecular Ecology 12:1855-1867. DOI: 10.1046/j.1365-294X.2003.01857.x.

Oberdorff T, Dias MS, Jézéquel C, Albert JS, Arantes CC, Bigorne R, Carvajal-valleros FM, Wever A De, Frederico RG, Hidalgo M, Hugueny B, Leprieur F, Maldonado M. 2019. Unexpected fish diversity gradients in the Amazon basin. Science Advances 5:1-9. DOI: 10.1126/sciadv.aav8681.

Ohara WM, Lima FCT, Salvador GN, Andrade MC. 2017. Ordem Perciformes. In: Ohara WM, 
714

715

716

717

718

719

720

721

722

723

724

725

726

727

728

729

730

731

732

733

734

735

736

737

738

739

740

741

742

743

744

745

746

747

748

749

750

751

752

753

754

755

756

757

758

759

Lima FCT, Salvador GN, Andrade MC eds. Peixes do rio Teles Pires - Diversidade e guia de identificação. Aparecida de Goiânia: Gráfica Amazonas e Editora Ltda EPP, 371-373.

Oliveira RC, Deprá GC, Zawadzki CH, Silva JCB, Graça WJC. 2020. Checklist of the fishes from Jamari River basin, in areas under influence of dams, Rondônia, Brazil Inventory. Biota Neotropica 20:1-15. DOI: 10.1590/1676-0611-BN-2019-0803.

Ota RR, Deprá GC, Graça WJ, Pavanelli CS. 2018. Peixes da planície de inundação do alto rio Paraná e áreas adjacentes: revised, annotated and updated. Neotropical Ichthyology 16:1111. DOI: $10.1590 / 1982-0224-20170094$.

Ota RP, Machado VN, Andrade MC, Collins RA, Farias IP, Hrbek T. 2020. Integrative taxonomy reveals a new species of Pacu (Characiformes: Serrasalmidae: Myloplus) from the Brazilian Amazon. Neotropical Ichthyology 18:1-22. DOI: 10.1590/1982-022420190112.

Ottoni FP, Mattos JLO, Katz AM, Bragança PHN. 2019. Phylogeny and species delimitation based on molecular approaches on the species of the Australoheros autrani group (Teleostei, Cichlidae), with biogeographic comments. Zoosystematics and Evolution 95:4964. DOI: 10.3897/zse.95.31658.

Papadopoulou A, Bergsten J, Fujisawa T, Monaghan MT, Barraclough TG, Vogler AP. 2008. Speciation and DNA barcodes: testing the effects of dispersal on the formation of discrete sequence clusters. Philosophical Transactions of the Royal Society B: Biological Sciences 363:2987-2996. DOI 10.1098/rstb.2008.0066.

Papadopoulou A, Monaghan MT, Barraclough TG, Vogler AP. 2009. Sampling error does not invalidate the Yule-coalescent model for species delimitation. A response to Lohse (2009). Systematic Biology 58: 442-444. DOI 10.1093/sysbio/syp038.

Pereira LHG, Hanner R, Foresti F, Oliveira C. 2013. Can DNA barcoding accurately discriminate megadiverse Neotropical freshwater fish fauna? BMC Genetics 14:1-14. DOI: doi.org/10.1186/1471-2156-14-20.

Pereira LHG, Maia GMG, Hanner R, Foresti F, Oliveira C. 2011. DNA barcodes discriminate freshwater fishes from the Paraíba do Sul River Basin, São Paulo, Brazil. Mitochondrial DNA 22:71-79. DOI: 10.3109/19401736.2010.532213.

Puillandre N, Lambert A, Brouillet S, Achaz G. 2012. ABGD, Automatic Barcode Gap Discovery for primary species delimitation. Molecular Ecology 21:1864-1877. DOI: 10.1111/j.1365-294X.2011.05239.x.

R Development Core Team. 2011. R: A language and Environmental for Statistical Computing: R Foundation for Statistical Computing: available on internet at http:// www.r-project.or. DOI: $10.1007 / 978-3-540-74686-7$.

Rambaut A, Drummond AJ, Xie D, Baele G, Suchard MA. 2018. Posterior summarization in Bayesian phylogenetics using Tracer 1.7. Systematic Biology 67:901-904. DOI: 10.1093/sysbio/syy032.

Regan CT. 1906. A revision of the South-American Cichlid genera Retroculus, Geophagus, Heterogramma, and Biotoecus. Annals and Magazine of Natural History 17:49-66. DOI: 10.1080/00222930608562489.

Reid NM, Carstens BC. 2012. Phylogenetic estimation error can decrease the accuracy of species delimitation: a Bayesian implementation of the general mixed Yule-coalescent model. BMC Evolutionary Biology 12:1-11. DOI: 10.1186/1471-2148-12-196.

Reis RE, Albert JS, Dario F Di, Mincarone MM, Petry P, Rocha LA. 2016. Fish biodiversity and conservation in South America. Journal of Fish Biology 89:12-47. DOI: 10.1111/jfb.13016.

Peer) reviewing PDF | (2021:06:63116:1:0:NEW 7 Oct 2021) 
760

761

762

763

764

765

766

767

768

769

770

771

772

773

774

775

776

777

778

779

780

781

782

783

784

785

786

787

788

789

790

791

792

793

794

795

796

797

798

799

800

801

802

803

804

805

Ř́ičan O, Ŕíčanová Š, Dragová K, Piálek L, Almirón A, Casciotta J. 2018. Species diversity in Gymnogeophagus (Teleostei: Cichlidae) and comparative biogeography of cichlids in the Middle Paraná basin, an emerging hotspot of fish endemism. Hydrobiologia 832:331-354. DOI: $10.1007 / \mathrm{s} 10750-018-3691-z$.

Rodríquez MA, Winemiller KO, Lewis WMJ, Baechle DCT. 2007. The freshwater habitats, fishes, and fisheries of the Orinoco River basin. Aquatic Ecosystem Health and Management Society 10:140-152. DOI: 10.1080/14634980701350686.

Sambrook J, Fritsch EF, Maniatis T. 1989. Molecular Cloning: a laboratory manual. New York: Cold Spring Harbor Laboratory press.

Sampaio ALA, Goulart E. 2011. Ciclídeos Neotropicais: Ecomorfologia trófica. Oceologia Australis 15:775-798. DOI: 10.4257/oeco.2011.1504.03.

Santos JCM dos, Ferreira ES, Oliveira C, Oliveira TB, Costa ASL da, Queiroz AKO, Schneider H, Sampaio I, Santos S. 2019. Phylogeny of the genus Hypophthalmus Cuvier, 1829 (Pimelodidae - Siluriformes), based on a multilocus analysis, indicates diversification and introgression in the Amazon basin. Molecular Phylogenetics and Evolution 137:285-292. DOI: 10.1016/j.ympev.2019.05.017.

Santos M da CF, Hrbek T, Farias IP. 2018. A Multilocus Approach to Understanding Historical and Contemporary Demography of the Keystone Floodplain Species Colossoma macropomum (Teleostei: Characiformes). Frontiers in Genetics 9:1-17. DOI: 10.3389/fgene.2018.00263.

Schliep KP. 2011. Phangorn: phylogenetic analysis in R. Bioinformatics 27:592-593. DOI: 10.1093/bioinformatics/btq706.

Sigovini M, Keppel E, Tagliapietra D. 2016. Open Nomenclature in the biodiversity era. Methods in Ecology and Evolution 7:1217-1225. DOI: 10.1111/2041-210X.12594.

Silva-Oliveira C, Canto ALC, Ribeiro FRV. 2015. Bryconops munduruku (Characiformes: Characidae), a new species of fish from the lower Tapajós River basin, Brazil. Zootaxa 3994:133-141. DOI: http://dx.doi.org/10.11646/zootaxa.3994.1.7.

Silva-Oliveira C, Canto ALC, Ribeiro FRV. 2016. Stream ichthyofauna of the Tapajós National Forest, Pará, Brazil. ZooKeys 144:125-144. DOI: 10.3897/zookeys.580.6659.

Smith WL, Chakrabarty P, Sparks JS. 2008. Phylogeny, taxonomy, and evolution of Neotropical cichlids (Teleostei: Cichlidae: Cichlinae). Cladistics 24:625-641. DOI: doi:10.1111/j.10960031.2008.00210.x.

Soares MGM, Costa EL, Siqueira-Souza FK, Anjos HDB, Yamamoto KC, Freitas CEC. 2008. Peixes de lagos do médio rio Solimões. Manaus-Am: Instituto Piatam.

Souza CR, de Mello Affonso PRA, de Araújo Bitencourt J, Sampaio I, Carneiro PLS. 2018. Species validation and cryptic diversity in the "Geophagus" brasiliensis Quoy \& Gaimard, 1824 complex (Teleostei, Cichlidae) from Brazilian coastal basins as revealed by DNA analyses. Hydrobiologia 809:309-321. DOI: 10.1007/s10750-017-3482-y.

Torati LS, Taggart JB, Varela ES, Araripe J, Wehner S. 2019. Genetic diversity and structure in Arapaima gigas populations from Amazon and Araguaia-Tocantins river basins. BMC Genetics 20:1-13. DOI: doi.org/10.1186/s12863-018-0711-y.

Torrente-vilara G, Zuanon J, Leprieur F, Oberdorff T, Tedesco PA. 2011. Effects of natural rapids and waterfalls on fish assemblage structure in the Madeira River (Amazon Basin). Ecology and Freshwater Fish 20:588-597. DOI: 10.1111/j.1600-0633.2011.00508.x.

Tougard C, García Dávila CR, Römer U, Duponchelle F, Cerqueira F, Paradis E, Guinand B, Angulo Chávez C, Salas V, Quérouil S, Sirvas S, Renno JF. 2017. Tempo and rates of

PeerJ reviewing PDF | (2021:06:63116:1:0:NEW 7 Oct 2021) 
806 diversification in the South American cichlid genus Apistogramma (Teleostei: Perciformes: 807 Cichlidae). PLoS ONE 12:1-19. DOI: 10.1371/journal.pone.0182618.

808 Winemiller KO, McIntyre PB, Castello L, Fluet-Chouinard E, Giarrizzo T, Nam S, Baird IG, 809

810

811

812

813

814

815 Darwall W, Lujan NK, Harrison I, Stiassny MLJ, Silvano RAM, Fitzgerald DB, Pelicice FM, Agostinho AA, Gomes LC, Albert JS, Baran E, Jr MP, Zarfl C, Mulligan M, Sullivan JP, Arantes CC, Sousa LM, Koning AA, Hoeinghaus DJ, Sabaj M, Lundberg JG,

822 Armbruster J, Thieme ML, Petry P, Zuanon J, Vilara GT, Snoeks J, Ou C, Rainboth W, Pavanelli CS, Akama A, Soesbergen A Van, Sáenz L. 2016. Balancing hydropower and biodiversity in the Amazon, Congo, and Mekong. Science 351:128-130. DOI: 10.1126/science.aac7082.

Yu G, Smith DK, Zhu H, Guan Y, Lam TTY. 2017. Ggtree: an R package for visualization and annotation of phylogenetic trees with their covariates and other associated data. Methods in Ecology and Evolution 8:28-36. DOI: 10.1111/2041-210X.12628.

Zhang J, Kapli P, Pavlidis P, Stamatakis A. 2013. A general species delimitation method with applications to phylogenetic placements. Bioinformatics 29:2869-2876. DOI: 10.1093/bioinformatics/btt499. 


\section{Table $\mathbf{1}$ (on next page)}

Summary statistics of the morpho-species analyzed in this study, including nominal species and candidate species (Geophagus sp.).

From the left to the right: number of individuals, number of haplotypes, number of sampled major drainages, number of sampled localities, maximum intraspecific divergence ( $p$ distance), minimum interspecific divergence ( $p$-distance), monophyly, and number of delimited clusters by each method (GMYC, bGMYC, MPTP, LocMin). 


\begin{tabular}{|c|c|c|c|c|c|c|c|c|c|c|c|}
\hline species & indivs & nHaps & drainages & localities & maxIntraDist & minInterDist & monophyly & gmyc & bgmyc & mptp & locmin \\
\hline Geophagus altifrons & 104 & 33 & 22 & 39 & 0.023 & 0.021 & True & 5 & 2 & 1 & 1 \\
\hline Geophagus argyrostictus & 17 & 13 & 2 & 3 & 0.009 & 0.021 & True & 1 & 1 & 1 & 1 \\
\hline Geophagus dicrozoster & 1 & 1 & 1 & 1 & 0 & 0.044 & Singleton & 1 & 1 & 1 & 1 \\
\hline Geophagus harreri & 1 & 1 & 1 & 1 & 0 & 0.079 & Singleton & 1 & 1 & 1 & 1 \\
\hline Geophagus megasema & 26 & 11 & 8 & 9 & 0.022 & 0.012 & True & 3 & 1 & 1 & 1 \\
\hline Geophagus mirabilis & 5 & 3 & 1 & 1 & 0.003 & 0.023 & True & 1 & 1 & 1 & 1 \\
\hline Geophagus proximus & 60 & 11 & 9 & 11 & 0.021 & 0.006 & True & 2 & 2 & 1 & 1 \\
\hline Geophagus sp. 1 & 57 & 21 & 13 & 22 & 0.019 & 0.012 & True & 4 & 1 & 1 & 1 \\
\hline Geophagus sp. 2 & 10 & 3 & 1 & 2 & 0.002 & 0.021 & True & 1 & 1 & 1 & 1 \\
\hline Geophagus sp. 3 & 22 & 9 & 3 & 5 & 0.013 & 0.025 & True & 3 & 1 & 1 & 1 \\
\hline Geophagus sp. 4 & 3 & 3 & 1 & 1 & 0.005 & 0.023 & True & 1 & 1 & 1 & 1 \\
\hline Geophagus sp. 5 & 4 & 4 & 3 & 3 & 0.013 & 0.021 & True & 2 & 1 & 1 & 1 \\
\hline Geophagus sp. 6 & 7 & 3 & 1 & 1 & 0.002 & 0.085 & True & 1 & 1 & 1 & 1 \\
\hline Geophagus steindachneri & 2 & 2 & 1 & 1 & 0.002 & 0.13 & True & 1 & 1 & 1 & 1 \\
\hline Geophagus sveni & 8 & 3 & 3 & 5 & 0.004 & 0.029 & True & 1 & 1 & 1 & 1 \\
\hline Geophagus winemilleri & 10 & 6 & 2 & 5 & 0.018 & 0.006 & True & 2 & 1 & 1 & 1 \\
\hline
\end{tabular}




\section{Figure 1}

Map showing all the sites sampled in this study, including data accessed from GenBank and BOLD databases when available.

A total of 77 localities were sampled. A small amount of random variation to the location of each point was added to prevent overplotting. The symbols refer to the morpho-species identified a priori in this study, and the colors refer to the lineages found in bGMYC analysis. The map was constructed in R 4.0.0 using packages 'ggspatial', 'raster', 'rgdal', 'rnaturalearth', and 'tidyverse'. The final image was edited in Inkscape.

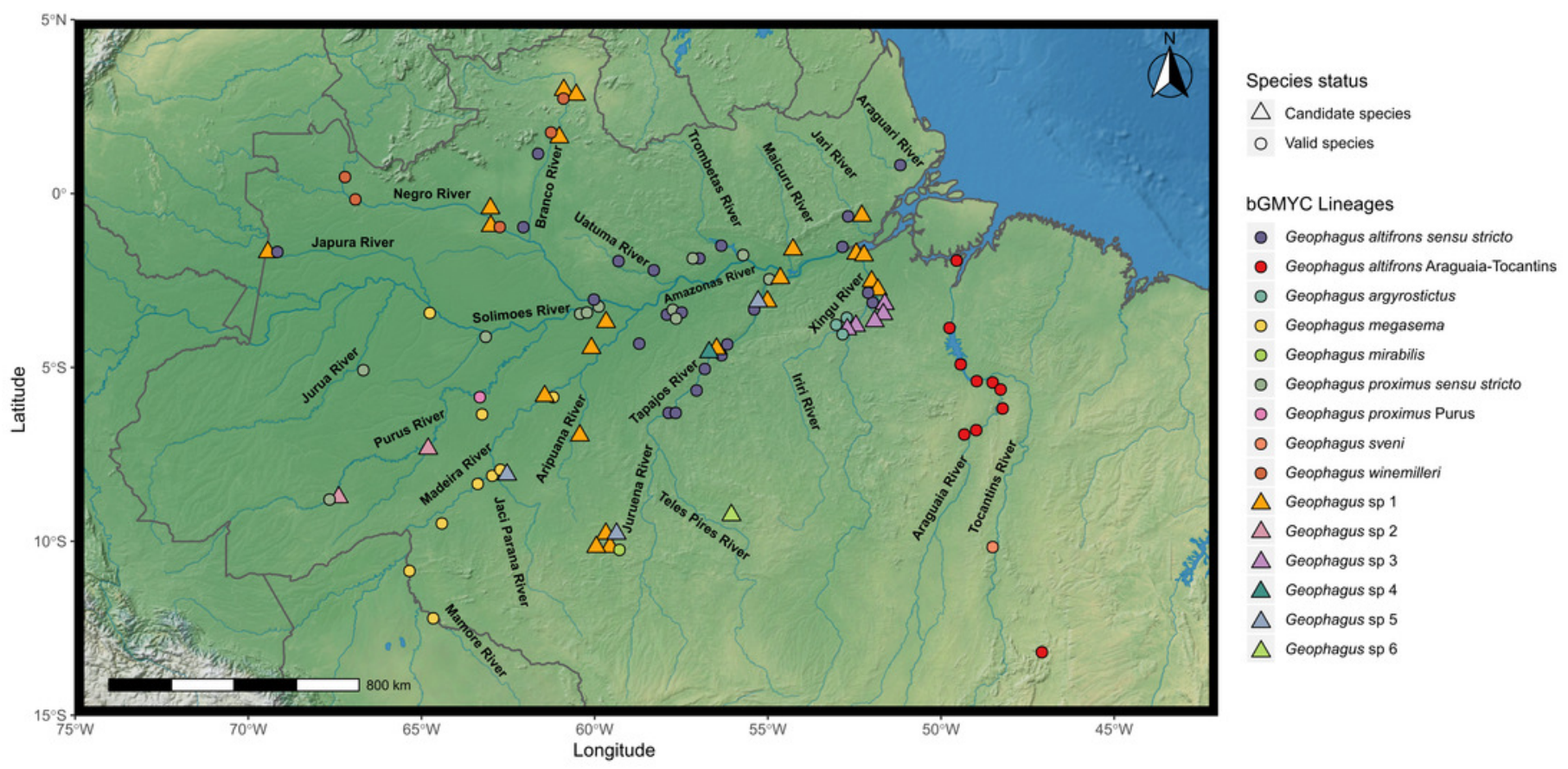




\section{Figure 2}

Maximum clade credibility chronogram from 9,000 posterior trees generated using BEAST 2.6.

Dataset comprised 127 unique haplotypes (from a total 337) of Geophagus COI sequences. Bayesian posterior probabilities above 0.95 are shown as dark nodes. Species delimitations are shown by method as colored boxes. The number of collapsed individuals is indicated in parentheses and outside of it the locations where they were sampled. The tree was constructed in R 4.0.0 using the package 'ggtree' and the final graphic in Inkscape. 

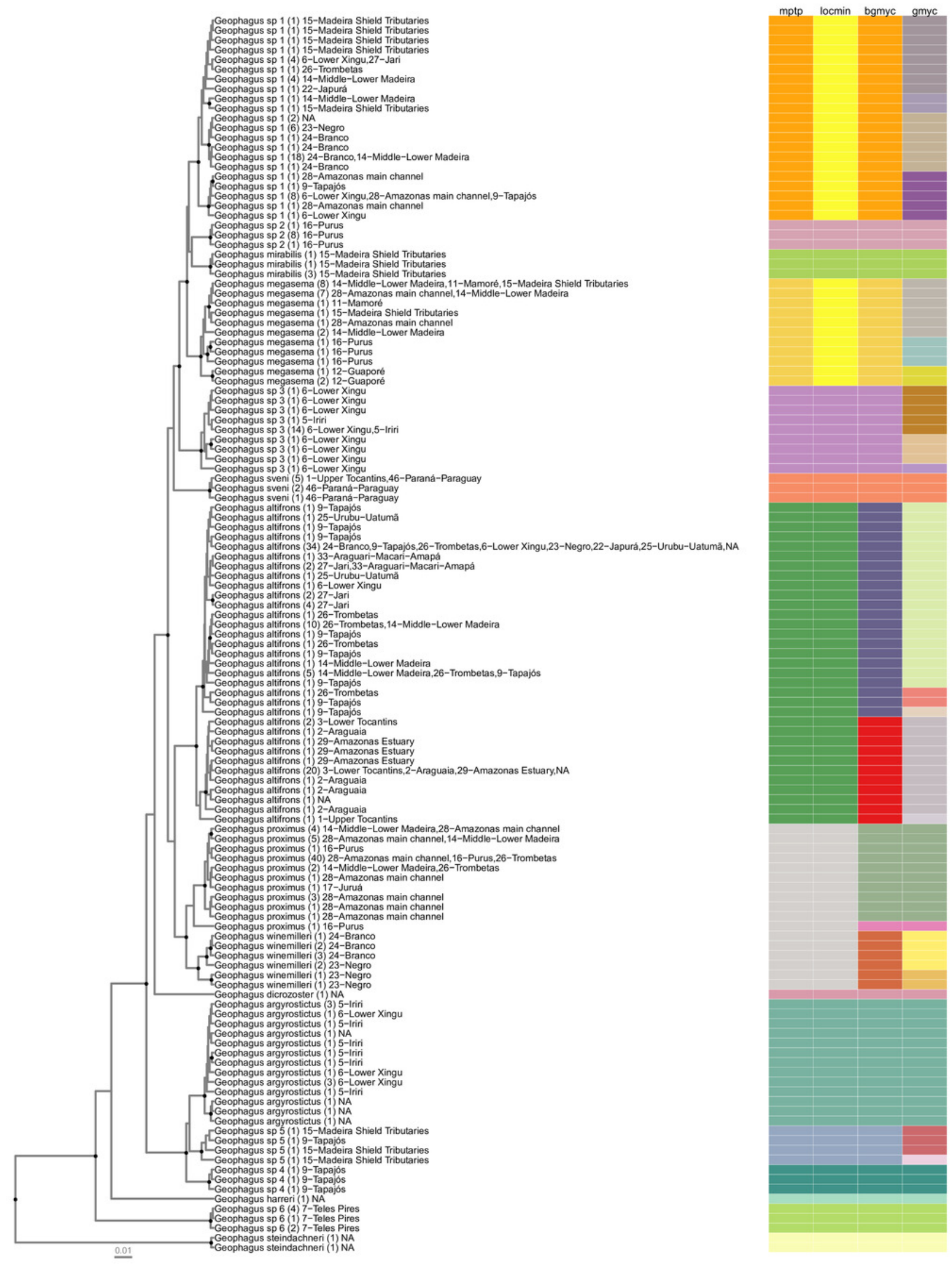